\title{
PENGARUH FAKTOR SOSIAL DAN EKSPEKTASI KINERJA TERHADAP TAX BILLING SYSTEM
}

\author{
Wiwit Irawati ${ }^{1}$, Beny Priambodo ${ }^{2}$ \\ ${ }^{1,2}$ Program Studi Akuntansi S1, Fakultas Ekonomi, Universitas Pamulang \\ wiwitira@unpam.ac.id
}

\begin{abstract}
This study aims to examine the effect of Social Factors and Performance Expectations on the use of a tax billing system application. Performance Expectations are intended to use a tax billing system application to help improve performance. Social factors mean that other people convince themselves that he must use a new system. This study uses a type of research with a quantitative approach. The population in this study are all corporate taxpayers who are registered at Kebayoran Lama Primary Tax Service Office, South Jakarta. The sampling technique used in determining the sample in this study was incidental sampling (convenience sampling) using 100 respondents. Based on the results of the analysis that has been done, this study shows that performance expectations have a positive effect on the Tax Billing System as well as social factors that have a positive effect on the Tax Billing System. Together, Performance Expectations and Social Factors influence the Tax Billing System.
\end{abstract}

Keywords: Performance expectations; Social factors; Tax billing system

\section{Abstrak}

Kajian ini bertujuan untuk menguji pengaruh Faktor Sosial dan Ekspektasi Kinerja pada penggunaan Tax Billing System. Ekspektasi Kinerja dimaksudkan dengan menggunakan aplikasi Billing System kinerja diharapkan akan meningkat. Faktor sosial dapat diartikan dengan adanya keyakinan yang berasal dari pengaruh sosial untuk menggunakan sistem baru. Penelitian ini menggunakan jenis penelitian dengan pendekatan kuantitatif. Populasi dalam penelitian ini adalah seluruh Wajib Pajak Badan yang terdaftar di Kantor Pelayanan Pajak Pratama Kebayoran Lama Jakarta Selatan. Teknik pengambilan sampel yang digunakan dalam penentuan sampel dalam penelitian ini adalah pengambilan sampel secara insidental (convenience sampling) terhadap 100 responden. Berdasarkan hasil analisis yang telah dilakukan, penelitian ini menunjukkan bahwa Ekspektasi Kinerja berpengaruh positif terhadap Tax Billing System demikian juga dengan variabel Faktor Sosial yang berpengaruh positif terhadap Tax Billing System. Secara bersama-sama Ekspektasi Kinerja dan Faktor Sosial berpengaruh terhadap Tax Billing System.

Kata Kunci: Tax billing system; Ekspektasi kinerja; Faktor sosial

Cronicle of Article: Received (August); Revised (November); and Published (December).

C2020 Jurnal Kajian Akuntansi Lembaga Penelitian Universitas Swadaya Gunung Jati.

Profile and corresponding author: Wiwit Irawati and Beny Priambodo are from the Accounting Study Program, Faculty of Economics, Universitas Pamulang.Corresponding Author: wiwitira@unpam.ac.id

How to cite this article: Irawati,W. \& Priambodo, B. (2020). Pengaruh Faktor Sosial dan Ekspektasi Kinerja terhadap Tax Billing System. Jurnal Kajian Akuntansi. Jurnal Kajian Akuntansi. 4 (2), 156-169. 


\section{PENDAHULUAN}

Pemerintah sangat berkepentingan terhadap penerimaan negara dari sektor pajak, salah satu usaha yang dilakukan pemerintah untuk terus meningkatkan penerimaan dari sektor pajak adalah dengan meningkatkan pelayanannya kepada Wajib Pajak. Mulai dari perbaikan dari segi kemudahan pemberian informasi kepada Wajib Pajak, kemudahan dari sisi pelaporan hingga pembayaran pajak. Agar program pemerintah ini mencapai tujuannya, maka pada awalnya membutuhkan sosialisasi dan penyebaran informasi kepada Wajib Pajak dan stakeholder lainnya. Sosialisasi informasi ini diharapkan akan menambah pengetahuan Wajib Pajak yang pada akhirnya akan menimbulkan kesadaran Wajib Pajak akan hak dan kewajibannya yang akan berusaha untuk dipenuhi dalam wujud kepatuhan.

Demikian juga pemerintah wajib untuk meningkatkan kapasitas Direktorat Jenderal Pajak (DJP) yang meliputi penguatan sumber daya manusia, teknologi informasi, dan anggaran untuk mendukung layanan, seperti yang disampaikan oleh Menteri Keuangan (Menkeu) Sri Mulyani Indrawati dalam sidang paripurna di Gedung Parlemen, Jakarta, (18/7/2017) tentang Delapan Strategi Menkeu Tingkatkan Penerimaan Pajak.

Salah satu peningkatan program layanan yang sudah diterapkan adalah layanan $E$ Government. E-Government merupakan wujud usaha pemerintah untuk meningkatkan kualitas layanannya kepada wajib pajak dalam bentuk sistem elektronik. Selain itu dengan $E$ Government pemerintah juga memperluas sarana penyebaran informasi kepada stakeholder terkait, baik internal maupun ekternal.

Di bidang pajak pemerintah menerapkan aplikasi billing system. Billing system ini dirancang untuk memudahkan wajib pajak dalam pembayaran kewajiban perpajakannya. Billing system menggunakan bantuan e-payment seperti ATM dan e-banking. Billing system ini dibuat untuk memudahkan serta mempercepat transaksi pelayanan pembayaran pajak. Dengan kemudahankemudahan melalui sistem online ini, pemerintah dalam hal ini Dirjen Pajak berharap adanya peningkatan kepatuhan Wajib Pajak baik dari segi ketepatwaktuan pembayaran dan pelaporannya dan ujungnya akan meningkatkan penerimaan negara dari sektor pajak.

Kesuksesan dari billing system yang lebih dikenal dengan nama e-billing tidak terlepas dari peran serta masyarakat untuk mau dan mampu untuk menggunakannya. West dalam penelitiannya menghasilkan kesimpulan bahwa dengan menggunakan informasi digital pemerintah berpotensi untuk mengubah pemberian layanan dan sikap warga negara (West, 2004) Dengan ekspektasi dari masyarakat akan kinerja yang lebih baik dari pemerintah diharapkan e-billing ini akan semakin diminati untuk digunakan. Hasil ini memperkuat hasil penelitian sebelumnya yang menyatakan terdapat respon positif dari fiskus dan wajib pajak orang pribadi (WPOP) terhadap sistem pembayaran pajak dengan elektronik melalui e-billing. Demikian juga sebaliknya kesuksesan $e$ billing ini juga membutuhkan kinerja yang baik dari sistem informasi dan layanan $e$ billing itu sendiri. Sehingga Wajib Pajak merasa aman dan nyaman untuk menggunakannya (Murry, Sinarwati, \& Yuniarta, 2017). Hasil yang mirip ditemukan pada penelitian yang menggunakan variabel model unified theory of acceptance and use of technology (UTAUT) yang menyatakan ekspektasi kinerja, ekspektasi usaha, pengaruh rekan kerja dari faktor manusia dan pelatihan dari faktor organisasi berpengaruh terhadap Sistem Informasi Pengendalian Keuangan Daerah (Sari, Rosidi, \& Roekhudin, 2016).

Didukung kemudian dengan hasil penelitian yang menunjukkan bahwa dua 
variabel UTAUT (ekspektasi kinerja dan pengaruh sosial) mempengaruhi penggunaan sistem secara signifikan (Nugroho, Susilowati, Ambarwati, \& Pratiwi, 2018). Persepsi yang baik dari masyarakat yang ditunjukkan melalui faktor sosial yakni dukungan dari lingkungan kerja, atasan, teman, mitra berpengaruh positif terhadap penggunaan sistem. Hal ini senada dengan penelitian mengenai Modul Penerimaan Negara Generasi ke II (MPN G2) di KPPN Makasar (Azis, 2018). Modernisasi perpajakan antara lain yang dilakukan dengan penggunaan e-filling, e-faktur dan e-billing memberikan kemudahan wajib pajak terutama dalam hal pemrosesan data (Rusli, 2019). Dengan kemudahaan yang ditawarkan dari modernisasi perpajakan terutama dengan penggunaan tax billing system diharapkan akan berujung kepada bertambahnya penerimaan negara dari sektor pajak, meskipun besarnya penerimaan pajak lebih dipengaruhi oleh tingkat perekonomian suatu wilayah (Jawas, Diatmika, AK, \& Yasa, 2018)

Penelitian ini menggunakan Theory of Reason Action untuk memperlihatkan motivasi dan persepsi Wajib Pajak terhadap penggunaan tax billing system melalui variabel Ekspektasi Kinerja dan Faktor Sosial, dengan hasil yang memperkuat teori bahwa Faktor Sosial dan Ekspektasi Kinerja berpengaruh positif terhadap Tax Billing System. Hasil yang sama dengan penggunaan Task Technology Fit Theory, didapatkan hasil Tax Billing System bermanfaat mempermudah Wajib pajak dalam penyetoran pajak, terlihat dari Ekspektasi Kinerja yang berpengaruh positif terhadap Tax Billing System. Hasil penelitian ini dapat digunakan KPP Pratama Kebayoran Lama khususnya dan fiskus dalam hal ini DJP pada umumnya sebagai bahan evaluasi dan pertimbangan dalam menentukan kebijakan di bidang perpajakan dengan cara meningkatkan performa dari layanan elektroniknya sehingga penerimaan pajak meningkat dengan lebih efisien.

\section{KAJIAN PUSTAKA \\ Theory of Reasoned Action}

Teori ini menjelaskan sikap dan tingkah laku seseorang dalam bertindak menggambarkan persepsi dan motivasi masing-masing. TRA merupakan model yang dikembangkan dari teori psikologis, (Ajzen \& Fishbein, 1980). TRA berfokus pada faktor kognitif (keyakinan dan nilainilai) yang menentukan motivasi (niat perilaku) (Montano, Kasprzyk, \& practice, 2015). Seseorang akan bertindak dikarenakan adanya motivasi atau dorongan dalam dirinya yang terbentuk melalui persepsi dari pengetahuannya, dan ditunjukkan melalui perilaku tertentu (Rosnidah et al., 2018).

Jika Wajib Pajak merasa yakin bahwa dengan menggunakan Billing System, pembayaran pajaknya akan lebih cepat dan aman, maka diharapkan hal ini akan meningkatkan volume transaksi pembayaran pajak, juga meningkatkan jumlah pembayaran pajaknya. Pada masyarakat dengan keyakinan dan nilainilai yang kuat maka, kepatuhan akan lebih mudah dicapai, yang berarti Billing System akan digunakan dengan baik atau malah sebaliknya Billing System tidak akan digunakan, dan hal ini tergantung dari kondisi sosial masyarakat.

\section{Task Technology Fit Theory}

Teori ini menjelaskan kesesuaian antara kemampuan atau kapabilitas dari suatu teknologi dengan tugas yang harus diselesaikannya apakah sudah mendukung pekerjaan tersebut atau sebaliknya (Goodhue \& Thompson, 1995). Teori ini awalnya diperkenalkan oleh Goodhue dan Thompson pada tahun 1995. Diperjelas pada penelitian selanjutnya yang mengatakan bahwa penggunaan teknologi informasi yang tepat berdampak positif terhadap kinerja individu (Gebauer, Shaw, \& Gribbins, 2010). 
Task Technology Fit menjelaskan hubungan antara kapabilitas individu, tugas yang diembannya serta teknologi yang digunakan. Relevansi teknologi yang digunakan atau yang masih dapat dikembangkan menjadi hal yang dipertimbangkan. Kesesuaian ini penting untuk dapat menentukan keberhasilan suatu sistem informasi entitas, yakni teknologi tersebut dapat digunakan dan membantu pelaksanaan tugas lebih efektif dan efisien sehingga mendatangkan dampak positif bagi entitas. Goodheu dan Thompson dalam penelitiannya menyatakan dampak positif teknologi yang digunakan sesuai dengan kebutuhan pengguna.

\section{Faktor Sosial terhadap Billing System} Pajak

Theory of Reason Action menyatakan bahwa setiap individu bertindak dikarenakan adanya niat dan keyakinan (Fishbein, 1979). Faktor sosial adalah pengaruh dari lingkungan yang meyakinkan seseorang untuk menggunakan suatu sistem. Keputusan penggunaan system didasarkan pada dukungan sekitar terhadap sistem tersebut. Individu dan juga entitas dapat mengkaji penggunaan suatu sistem dengan melihat dukungan masyarakat terhadap sistem tersebut, apakah masyarakat setuju dengan sistem tersebut atau menolaknya, dengan melihat dukungan sosial, individu atau entitas akan semakin yakin untuk menggunakan sistem tersebut (Iriani, Suyanto, \& Amborowati, 2014). Hasil dari penelitian tersebut menyatakan faktor sosial berdampak terhadap penerimaan aplikasi SIPKD (Sistem Pengelolaan Keuangan Daerah). User merasa bahwa penerimaan terhadap aplikasi dipengaruhi oleh lingkungan kerja atau faktor sosial. Hasil penelitian ini didukung penelitian terdahulu yang menyatakan Faktor Sosial berpengaruh terhadap minat wajib pajak dalam menggunakan e-filing (Lie, 2013). Hal ini menandakan ada pengaruh yang tinggi dari lingkungan, teman, rekan kerja dan saudara kepada Wajib Pajak untuk menggunakan $e$-filing.

H1: Diduga Faktor Sosial mempunyai pengaruh positif signifikan terhadap Penggunaan Tax Billing System

\section{Ekspektasi Kinerja terhadap Tax Billing} System

Task Technology Fit menjelaskan hubungan antara kapabilitas individu, tugas yang diembannya serta teknologi yang digunakan (Goodhue \& Thompson, 1995). Ekspektasi kinerja merupakan tingkatan kepercayaan pengguna apakah jika pengguna menggunakan sistem tersebut akan dapat meningkatkan kinerjanya. Venkatesh dalam penelitiannya menggambarkan Ekspektasi Kinerja sebagai hubungan antara perceived usefulness, ekstrinsik motivation, job fit, dan relative advantage (Venkatesh et al 2003). Pengguna mempunyai ekpektasi bahwa kinerja mereka akan meningkat dengan menggunakan teknologi informasi. Definisi ekspektasi kinerja yang lain dengan menyatakan bahwa dengan menggunakan suatu sistem atau teknologi maka individu akan mendapatkan keuntungan dalam kinerjanya (Iriani et al., 2014). Ekspektasi Kinerja berpengaruh terhadap minat pemanfaatan billing system. Dengan melihat kegunaan, motivasi dan keuntungan yang dihasilkan dari penggunaan billing system, maka timbul minat untuk memanfaatan billing system oleh Wajib Pajak untuk meningkatkan kinerja mereka.

H2: Diduga Ekspektasi Kinerja berpengaruh terhadap Penggunaan Tax Billing System.

\section{Tax Billing System}

Sesuai dengan Peraturan Direktur Jendral Pajak Nomor PER-26/PJ/2014 Pasal 1 angka 1, yang dimaksud dengan Tax Billing System adalah sistem pembayaran pajak secara elektronik atau yang lebih familier dengan sebutan E-Billing. Dalam praktiknya sistem ini menggunakan bantuan Kode Billing yang diterbitkan oleh Dirjen Pajak yang akan digunakan oleh 
Wajib Pajak sebagai kode identifikasi setoran pajaknya.

Billing system dirjen pajak merupakan salah satu media e-government yang digunakan oleh dirjen pajak untuk mempermudah, mempercepat dan meminimalisasi kesalahan dalam pelayanan pembayaran pajak (Sulistyowati et al., 2020). Terdapat beberapa kelebihan di dalam sistem ini yakni tidak perlu antri di bank saat melakukan penyetoran pajak. Wajib pajak dapat membayar pajak melalui internet banking atau melalui mesin ATM . Wajib pajak juga tidak perlu lagi membawa lembaran SSP ke bank atau kantor pos. Untuk pembayaran secara manual di kantor pos dan bank, para wajib pajak cukup membawa catatan kecil berisi kode unik yang diterbitkan oleh sistem ini wajib pajak akan memiliki akun khusus yang dapat digunakan untuk menerbitkan kode unik yang dinamakan kode billing. Kode ini diperoleh Wajib Pajak setelah pengisian data-data pajak yang diperlukan secara elektronik sudah sesuai, untuk kemudian digunakan sebagai kode identifikasi setoran pajaknya.

Model penelitian ditunjukkan pada gambar berikut:

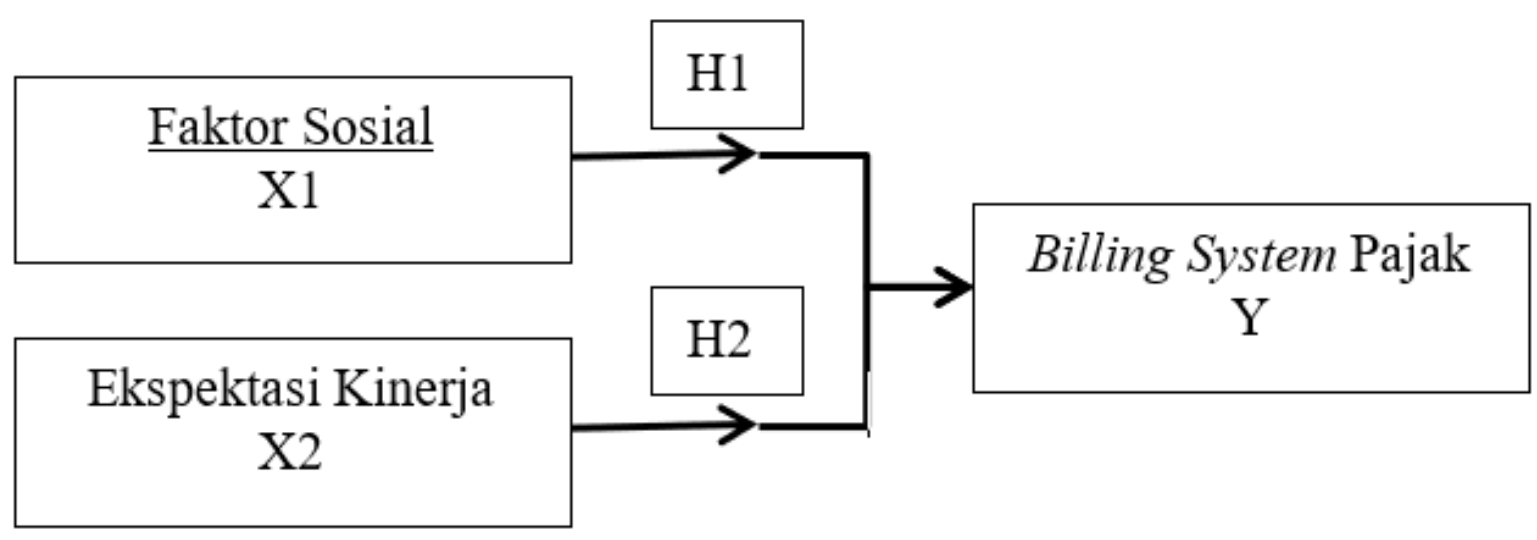

Gambar 1. Model Penelitian

\section{METODE PENELITIAN}

Penelitian ini menggunakan populasi seluruh Wajib Pajak yang terdaftar pada KPP Pratama Jakarta, Kebayoran Lama. Menggunakan teknik pemilihan sampel sederhana atau Simple Random Sampling. Teknik ini dipilih dengan untuk mengatasi keterbatasan waktu, biaya, dan tenaga yang dimiliki peneliti.

Tabel 1. Item Pertanyaan

\begin{tabular}{llll}
\hline \multicolumn{1}{l}{ Variabel } & Pernyataan & Skala \\
\hline 1 & Faktor Sosial & FS1 & likert \\
& & FS2 & likert \\
& & FS3 & likert \\
& Ekspektasi Kinerja & FS4 & likert \\
& & FS5 & likert \\
& & FS6 & likert \\
& & EK 1 & likert \\
& & EK2 & likert \\
& EK3 & likert \\
\end{tabular}

Data didapatkan dari hasil menyebar kuesioner (hardcopy) kepada 100 orang responden Wajib Pajak Orang Pribadi yang terdaftar di KPP Pratama Jakarta Kebayoran Lama, pada Bulan Februari dari perhitungan menggunakan Rumus Slovin. 2019. Jumlah responden merupakan hasil 


\begin{tabular}{lll}
\hline 3 Tax Billing System & EK5 & likert \\
& TBS1 & likert \\
& TBS2 & likert \\
& TBS3 & likert \\
& TBS4 & likert \\
& TBS5 & likert \\
\hline
\end{tabular}

\section{Operasionalisasi Variabel \\ Faktor Sosial}

Dalam penelitian ini Faktor Sosial diukur dengan indikator sebagai berikut; (1) Tax Billing System digunakan menurut pendapat orang penting disekitar wajib pajak; (2) Tax Billing System digunakan karena pengaruh atasan dari Wajib Pajak; (3) Tax Billing System digunakan berdasarkan pengaruh perilaku orang lain; (4) Tax Billing System digunakan karena pengaruh rekan kerja dari Wajib Pajak; dan

(5) Perusahaan/ Organisasi mendukung penggunaan Tax Billing System.

\section{Ekspektasi Kinerja}

Dalam penelitian ini Ekspektasi Kinerja diukur dengan indikator sebagai berikut : peningkatan efektivitas kinerja Wajib Pajak, penyelesaian lebih cepat, peningkatan produktivitas dan peningkatan kualitas.

\section{Billing System Pajak}

Dalam penelitian ini Billing System Pajak diukur dengan indikator sebagai berikut, (Husnurrosyidah, 2017) : (1) Tax Billing System mempermudah, mempercepat, dan menyederhanakan proses pembayaran pajak; (2) Tax Billing System menghindari dan meminimalisir human eror karena telah terkomputerisasi; (3) Wajib Pajak lebih fleksibel untuk melakukan pembayaran pajak; (4) Tax Billing System membuat Wajib Pajak lebih leluasa memonitor status pembayaran pajaknya; (5) Tax Billing System membuat wajib pajak lebih leluasa merekam data secara mandiri.

\section{Uji Kualitas Instrument}

Uji Kualitas instrumen dilakukan menggunakan uji Validitas dan Uji
Reliabilitas. Instrumen dikatakan valid artinya alat ukur untuk menghasilkan data penelitiannya sudah bagus dan sesuai untuk pengukuran data (Janti, 2014). Uji validitas pada penelitian ini dilakukan dengan menggunakan Validitas Product Moment dengan SPSS versi 22. Untuk menentukan validitas dilakukan uji signifikansi dengan membandingkan nilai $r$ hitung dengan $r$ tabel untuk degree of freedom $(\mathrm{df})=\mathrm{n}-2$. Indikator atau butir pernyataan dinyatakan valid jika hasil perbandingannya menyatakan $r$ hitung lebih besar dari $r$ tabel.

.Uji Reliabilitas menunjukkan apakah hasil pengukuran tetap konsisten bila diukur beberapa kali dengan alat ukur yang sama (Janti, 2014). Untuk mengukur reliabititas digunakan Uji Reliabilitas dengan Alpha Cronbach's. Nilai koefisien reliabilitas atau Alpha (Cronbach) yang cukup baik adalah di atas 0,7 .

\section{Uji Asumsi Klasik}

Uji Asumsi Klasik dilakukan menggunakan tiga macam uji, yakni (1) Uji Normalitas Residual; (2) Uji Multikolinieritas; (3) Uji Heteroskedastisitas. Uji Normalitas adalah dengan melihat normalitas residual dari semua variabel penelitian. Uji Normalitas Residual dilakukan dengan menggunakan bantuan SPSS versi 22, yakni menggunakan Uji Kolmogorov Smirnov. Jika nilai Asymp. Sig. (2-tailed) > 0,05 maka dikatakan data berdistribusi normal. Dengan melihat grafik sebaran titik-titik data kita juga dapat menilai data yang berdistribusi normal, yakni yang sebarannya di sepanjang garis diagonal 
dapat dinyatakan sebagai data yang berdistribusi normal.

Uji Multikolinieritas dengan melihat hasil Collinearity Statistics dengan SPSS, untuk melihat apakah antara variabel-variabel bebas terdapat korelasi. Multikolinearitas dikatakan ada ketika terdapat 2 atau lebih variabel bebas yang digunakan dalam regresi saling berkorelasi menurut Mendenhall \& Sincich 1996 dalam Dewi, (Dewi, 2010). Idealnya tidak ada korelasi antar variabel bebas dalam penelitian. Data terbebas dari multikolinieritas jika nilai tolerance $>0,1$ dan nilai variance inflation factor (VIP) $<10$.

Varians residual idealnya adalah sama dari satu pengamatan ke pengamatan yang lain. Untuk mengujinya menggunakan Uji Heteroskeastisitas yang dapat dilakukan dengan melihat grafik Scatterplot. Jika grafik sebaran data tidak menunjukkan suatu pola yang jelas dan tersebar secara acak, dapat disimpulkan bahwa data bersifat homoskedastisitas dan baik untuk digunakan.

\section{Uji Statistik Deskriptif}

Pengujian dengan statistik deskriptif akan memberikan gambaran yang dilihat melalui nilai minimum, maksimum, ratarata, dan standar devisiasi. Dilakukan untuk mendapatkan gambaran umum mengenai data-data penelitian pada masing-masing variable uji signifikansi.

\section{HASIL PENELITIAN}

\section{Uji Statistik Deskriptif}

Tabel 2 menunjukan hasil uji statistic deskriptif yang diambil dari output SPSS 22 seperti yang ditunjukan pada tabel dibawah ini.

Tabel 2. Hasil Uji Statistik Deskriptif

\begin{tabular}{llllll}
\hline & $\mathrm{N}$ & Minimum & Maximum & Mean & Std. Deviation \\
\hline Faktor Sosial & 100 & 17 & 30 & 23,45 & 3,033 \\
Ekpektasi Kinerja & 100 & 11 & 25 & 18,30 & 3,027 \\
Tax Billing System & 100 & 18 & 45 & 33,63 & 5,829 \\
Valid N (listwise) & 100 & & & &
\end{tabular}

Sumber: SPSS 22, 2019 (diolah oleh penulis)

Melihat hasil di atas, untuk variabel Faktor Sosial nilai rata-rata adalah 23,45 dengan jumlah item 6 yang berarti rata-rata responden menjawab setuju. Hal ini menggambarkan mayoritas responden menggunakan Tax Billing System dikarenakan pengaruh sosial yakni terpengaruh lingkungan, rekan kerja dan atasan. Terlepas dari menggunakan $e$ billing sebagai suatu keharusan, responden mendapatkan bantuan dari rekan, fasilitas dari organisasi berupa pelatihan, dan lingkungan berupa sosialisasi serta informasi yang lain untuk menggunakan Tax Billing System.

Demikian juga untuk Ekspektasi Kinerja dengan nilai rata-rata 18,3 dengan jumlah item pernyataan 5, maka rata-rata responden menjawab setuju untuk variabel Ekpektasi Kinerja. Nilai rerata menggambarkan mayoritas responden menyatakan dengan menggunakan Tax billing System mereke mempunyai ekspektasi bahwa kinerja menjadi lebih berkualitas, pekerjaan lebih cepat selesai, sehinga produktivitas meningkat.

Sedangkan untuk Tax Billing System dengan jumlah item pernyataan 9, nilai rata-rata 33,63 yang berarti rerata responden menjawab setuju untuk pernyataan-pernyataan yang diajukan. Pernyataan setuju menggambarkan bahwa Tax Billing System membantu dan memudahkan mereka dalam proses pembayaran pajak.

\section{Hasil Uji Kualitas Instrumen}

Hasil Uji Validitas dengan melihat nilai nilai Pearson Corelation dan membandingkan nilai $r$ hitung dengan $r$ tabel. Jika $r$ hitung lebih dari $r$ tabel, maka item dinyatakan valid. Mencari $r$ tabel, $\mathrm{df}=\mathrm{N}-\mathrm{k}$, jadi $100-3=97,2$ arah dengan 
signifikansi 0,05 , untuk $\mathrm{N} 97$ adalah $=$ 0,1975. Dari Hasil SPSS diketahui bahwa semua item untuk setiap variabel baik variabel Ekspektasi Kinerja, Faktor Sosial dan Variabel Y Billing System Pajak menunjukkan hasil lebih besar dari $r$ hitung yang bernilai 0,1975 . Dapat dilihat dari tabel di bawah ini:

Tabel 3. Hasil Uji Validitas Butir

\begin{tabular}{llll}
\hline No. Butir & Faktor Sosial & r tabel & Keterangan \\
\hline FS1 & 0,534 & 0,1975 & valid \\
FS2 & 0,703 & 0,1975 & valid \\
FS3 & 0,741 & 0,1975 & valid \\
FS4 & 0,699 & 0,1975 & valid \\
FS5 & 0,668 & 0,1975 & valid \\
FS6 & 0,644 & 0,1975 & valid \\
Total & $\mathbf{1}$ & $\mathbf{0 , 1 9 7 5}$ & valid \\
No. Butir & Ekpektasi Kinerja & r tabel & Keterangan \\
EK1 & 0,682 & 0,1975 & valid \\
EK2 & 0,804 & 0,1975 & valid \\
EK3 & 0,835 & 0,1975 & valid \\
EK4 & 0,875 & 0,1975 & valid \\
EK5 & 0,683 & 0,1975 & valid \\
Total & $\mathbf{1}$ & $\mathbf{0 , 1 9 7 5}$ & valid \\
No. Butir & Tax Billing System & $\mathbf{r ~ t a b e l}$ & Keterangan \\
TBS1 & 0,665 & 0,1975 & valid \\
TBS2 & 0,676 & 0,1975 & valid \\
TBS3 & 0,735 & 0,1975 & valid \\
TBS4 & 0,882 & 0,1975 & valid \\
TBS5 & 0,733 & 0,1975 & valid \\
TBS6 & 0,812 & 0,1975 & valid \\
TBS7 & 0,678 & 0,1975 & valid \\
TBS8 & 0,783 & 0,1975 & valid \\
TBS9 & 0,655 & 0,1975 & valid \\
Total & $\mathbf{1}$ & $\mathbf{0 , 1 9 7 5}$ & valid \\
\hline
\end{tabular}

Sumber: SPSS 22, 2019 (diolah oleh penulis)

Tabel 4 Hasil Reliabilitas Butir

\begin{tabular}{clll}
\hline Instrumen & Cronbach's alpha & N of items & Keterangan \\
\hline Faktor Sosial & .747 & 5 & reliabel \\
Ekpektasi Kinerja & .831 & 6 & reliabel \\
Tax Billing System & .895 & 9 & reliabel \\
\hline
\end{tabular}

Sumber: SPSS 22, 2019 (diolah oleh penulis)

Uji Normalitas Residual dengan Uji Kolmogorov Smirnov. Jika nilai Asymp.
Sig. (2-tailed) $>0,05$ maka dikatakan data berdistribusi normal.

Tabel 5 Uji Normalitas

\begin{tabular}{lll}
\hline & & Unstandardized Residual \\
\hline N (jumlah sampel) & Mean & 100 \\
Normal & Std. Deviation & 000 \\
Parameters & Absolute & 5,290 \\
Most Extreme & Positive & .058 \\
Differences & Negative & .055 \\
& & -.058 \\
Asymp Sig (2-tailed) & & 200 \\
\hline
\end{tabular}

Sumber: SPSS 22, 2019 (diolah oleh penulis) 
Karena nilai siginifikansi di atas 0,05 maka dapat dikatakan data berdistribusi normal. Tabel berikut menyajikan hasil Uji Heteroskedastisitas yang menggambarkan data menyebar tidak teratur atau tidak mempunyai pola. Seperti ini dapat dinyatakan bahwa data bebas dari heteroskedastisitas atau data bersifat homokedastisitas

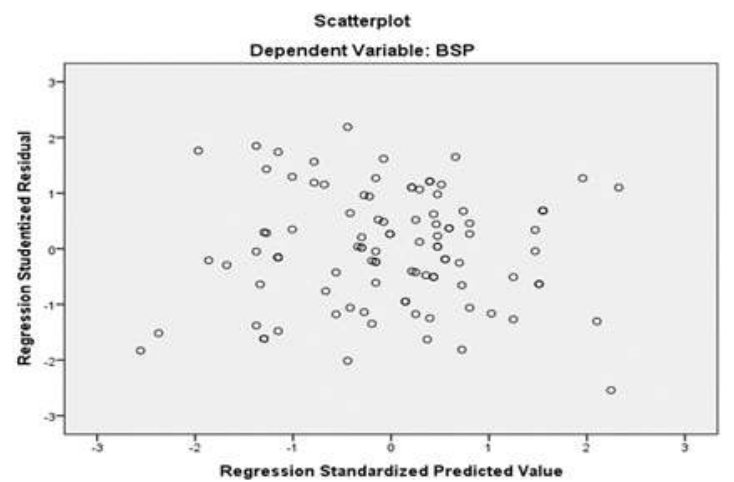

Gambar 2. Uji Heteroskedastisitas

Hasil uji Multikolinieritas adalah sebagaimana pada tabel di bawah ini.

Tabel 6. Hasil Uji Multikolinieritas

\begin{tabular}{llcc}
\hline Model & & \multicolumn{2}{c}{ Statistik Kolinieritas } \\
& & Tolerance & VIF \\
\hline 1 & (Constant) & & \\
& Faktor Sosial & .904 & 1.106 \\
& Eks Kinerja & .904 & 1.106 \\
\hline
\end{tabular}

Sumber: SPSS 22, 2019 (diolah oleh penulis)

Dengan melihat nilai pada kolom

Collinearity Statistics, di mana nilai tolerance semua lebih besar dari 0,1 dan nilai VIF semua di bawah 10, maka dapat dikatakan data terbebas dari multikolinieritas.

\section{Hasil Uji Hipotesis}

Penelitian ini menggunakan alat bantu SPSS versi 22, hipotesis simultan yang diujikan menghasilkan data sebagai berikut:

Tabel 7. Hasil Uji F Anova

\begin{tabular}{|c|c|c|c|c|c|c|}
\hline & Model & $\begin{array}{l}\text { Sum of } \\
\text { Squares }\end{array}$ & $d f$ & $\begin{array}{l}\text { Mean } \\
\text { Square }\end{array}$ & $F$ & Sig. \\
\hline \multirow[t]{3}{*}{1} & Regression & 592,511 & 2 & 296,255 & 10,371 &, $000^{6}$ \\
\hline & Residual & 2770,799 & 97 & 28,565 & & \\
\hline & Total & 3363,310 & 99 & & & \\
\hline
\end{tabular}

a. Dependent Variable: Billing System Pajak

b. Independent Variabels: Ekspektasi Kinerja dan Faktor Sosial

Nilai uji F 10,371 lebih besar dari F tabel dengan degree of freedom 2 dan tingkat kesalahan 0,05 atau 5\% sebesar 3,090 dan juga signifikansi lebih kecil dari taraf signifikansi 0,05 yang berarti Faktor Sosial dan Ekspektasi Kinerja berpengaruh signifikan terhadap Tax Billing System. Nilai signifikansi yang lebih kecil dari 0,05 juga mengindikasikan bahwa model regresi yang kita buat sudah cukup baik.
Persamaan regresi yang terbentuk dengan melihat nilai koefisien beta sebagai berikut:

$\mathrm{Y}=12,608+0,546 \mathrm{X} 1+0,449 \mathrm{X} 2+\mathrm{e}$

Koefisien Korelasi dengan melihat pada hasil uji Regresi linier berganda dengan bantuan SPSS versi 22, menghasilkan data sebagai berikut: 
Tabel 8. Koefisien Beta

\begin{tabular}{llcc}
\hline Model & & \multicolumn{2}{c}{ Unstandardized Coefficients } \\
& & B & Std. Error \\
\hline 1 & (Constant) & & \\
& Faktor Sosial & .904 & 1.106 \\
& Eks Kinerja & .904 & 1.106 \\
\hline
\end{tabular}

Sumber: SPSS 22, 2019 (diolah oleh penulis)

Koefisien Korelasi dengan melihat pada hasil uji Regresi linier berganda dengan

bantuan SPSS versi 22, menghasilkan data sebagai berikut:

Tabel 9. Uji Koefisien Korelasi dan Determinasi

\begin{tabular}{lllll}
\hline Model & $R$ & $R$ Square & $\begin{array}{l}\text { Adjusted } R \\
\text { Square }\end{array}$ & $\begin{array}{l}\text { Std. Error of the } \\
\text { Estimate }\end{array}$ \\
\hline 1 &, $420^{\mathrm{a}}$ &, 176 &, 159 & 5,345 \\
\hline
\end{tabular}

a. Dependent Variable: Billing System Pajak

b. Independent Variabels : Ekspektasi Kinerja dan Faktor Sosial

Tabel 10. Uji hipotesis

\begin{tabular}{llcccc}
\hline \multicolumn{1}{c}{ Model } & \multicolumn{2}{c}{$\begin{array}{c}\text { Standardized } \\
\text { Beta }\end{array}$} & T & Sig. \\
\hline 1 & (Constant) & & 2,701 &, 008 & \\
& Faktor Sosial &, 284 & 2,931 &, 004 & \\
& Eks Kinerja &, 233 & 2,407 &, 018 \\
\hline
\end{tabular}

Sumber: SPSS 22, 2019 (diolah oleh penulis)

Nilai $\mathrm{R}=0,420 \mathrm{a}$, berarti Faktor Sosial dan Ekspektasi Kinerja terhadap Tax Billing System mempunyai hubungan yang signifikan sebesar $42 \%$ atau berada dalam taraf sedang. Sedangkan nilai Adjusted $R$ Square menghasilkan nilai sebesaf 0,159 atau $15,9 \%$ yang berarti variabe $\mathrm{Y}$ yakni Tax Billing System dipengaruhi oleh 15,9 $\%$ oleh Faktor Sosial dan Ekspektasi Kinerja. Sedangkan sisanya yakni 100-15,9 $=84,1 \%$ dipengaruhi variabel lain yang tidak diteliti dalam penelitian ini.

\section{PEMBAHASAN}

Faktor Sosial terhadap Tax Billing System

Variabel Faktor Sosial secara parsial menunjukan $t$ hitung sebesar 2,931 dengan nilai signifikansi sebesar 0,04. Nilai $t$ hitung $<\mathrm{t}$ tabel $(2,931>1,661)$ dan nilai signifikansi $(0,004<0,05)$. Dari hasil uji t tersebut dapat dinyatakan bahwa Faktor Sosial memiliki pengaruh signifikan terhadap variabel Billing System Pajak.
Billing System sudah dilakukan oleh KPP Pratama Kebayoran Lama sejak 1 Januari 2016. Sesuai dengan Theory of Reason Action yang menyatakan bahwa ada keyakinan dan niat yang membuat wajib pajak menggunakan Tax Billing System. Keyakinan ini dapat diperoleh antara lain dari Faktor sosial yang merupakan salah satu faktor eksternal selain tata kelola yang dapat mempengaruhi efisiensi sistem (Dashti, Yousefi, \& Moghaddam, 2013). Keterjangkauan akses ke sistem terutama di daerah-daerah perlu mendapat perhatian pemerintah saat perancangan untuk mendapatkan metode yang sesuai dengan kebutuhan masyarakat (Rey-Moreno, Ufitamahoro, Venter, \& Tucker, 2014). Masyarakat terutamanya pelaku bisnis yang dapat diartikan Wajib Pajak potensial menginginkan sistem yang lebih baik untuk mengelola berbagai hal dalam hal ini pembayaran pajaknya sehingga waktu penyetoran pajak menjadi lebih efektif dan efisien dan tidak menganggu kelancaran 
aktivitas lainnya. (Bisaria \& Agarwal, 2017). Hasil penelitian bertolak belakang dengan penelitian Drajat Priyo Tri Atmojo (Atmojo, 2016) yang menyatakan bahwa Faktor Sosial tidak memiliki pengaruh signifikan terhadap variabel minat Pemanfaatan Sistem Informasi dan Penggunaan Sistem Informasi. Tetapi hasil penelitian ini menguatkan hasil penelitian Iriani dkk (2014) yang menyatakan faktor sosial berdampak terhadap penerimaan aplikasi SIPKD (Sistem Pengelolaan Keuangan Daerah). Hasil penelitian ini juga didukung dengan hasil penelitian Lie, I dkk yang menyatakan Faktor Sosial berpengaruh terhadap minat wajib pajak dalam menggunakan e-filing (Lie, 2013). Hal ini menandakan ada pengaruh yang tinggi dari lingkungan, teman, rekan kerja dan saudara kepada Wajib Pajak untuk menggunakan Billing System Pajak. Sehingga pemerintah perlu memperhatikan aspirasi dari masyarakat berupa saran dan kritik untuk perbaikan dan pengembangan sistem yang sudah ada (Im, 2014)

\section{Espektasi Kinerja terhadap Billing System Pajak}

Variabel Ekspektasi Kinerja secara parsial menunjukkan $\mathrm{t}$ hitung sebesar 2,407 dengan nilai signifikansi sebesar 0,018. Nilai $\mathrm{t}$ hitung $>\mathrm{t}$ tabel $(2,407>1,661)$ dan nilai signifikansi $(0,018<0,05)$. Dari hasil uji $t$ tersebut dapat dinyatakan bahwa Ekspektasi Kinerja memiliki pengaruh signifikan terhadap variabel Billing System Pajak. Penggunaan Billing System sudah dilakukan oleh KPP Pratama Kebayoran Lama sejak 1 Januari 2016 dan ditanggapi dengan cukup positif oleh Wajib Pajak dengan ekspektasi akan dapat meningkatkan kinerja pelayanan aparat perpajakan. Hal ini sesuai dengan Task Technology Fit Theory yang menjelaskan hubungan antara kapabilitas individu dengan deskjob masing-masing serta teknologi yang digunakan. Penggunaan ekspektasi kinerja di awal perancangan, sistem dapat didesain dengan pengukuran yang tidak melebihi ekspektasi pengguna dan hal ini dapat membantu untuk menentukan reaksi terhadap kegagalan sistem yang mungkin ada (Vetter \& Worley, 2002). Kegagalan suatu sistem dapat diakibatkan berbagai faktor antara lain perbedaan individu, praktik implementasi, dan penggunaan sistem itu sendiri (Aydin \& Rice, 1991). Pemerintah berkepentingan untuk mengurangi kesenjangan ekspektasi wajib pajak terhadap kinerja sistem bahwa ada kemungkinan sistem tidak berjalan dengan baik dengan terus menjaga performa sistem dan mensosialisasikannya ke user (Masoud, 2017). Hasil penelitian ini sejalan dengan penelitian Iriani, Syono dan Ambarawati (2014) yang menyimpulkan bahwa penerimaan aplikasi SIPKD dipengaruhi oleh faktor ekspektasi kinerja, ekspektasi usaha, pengaruh sosial dan kondisi yang memfasilitasi. Tetapi berlainan dengan hasil penelitian Drajat Priyo Tri Atmojo (2016) yang menyatakan bahwa Ekspektasi Kinerja tidak memiliki pengaruh signifikan terhadap variabel minat Pemanfaatan Sistem Informasi dan Penggunaan Sistem Informasi. Dengan menggunakan sistem, maka berbagi macam aktivitas akan dapat terintegrasi dan ini akan mempercepat suatu pekerjaan yang berarti akan lebih efisien dalam pemanfaatan waktu (Jayakody, Bulathsinghala, Lihinigama, Anurad, \& Karunarathna, 2019)

\section{KESIMPULAN \\ Kesimpulan}

1) Faktor Sosial berpengaruh positif terhadap Tax Billing System. Hal ini dapat disebabkan karena adanya dukungan dari lingkungan sosial responden untuk meningkatkan minat pemanfaatan dan penggunaan Tax Billing System. Hasil penelitian ini mendukung hasil penelitian Iriani dkk (2014) yang menyatakan faktor sosial berdampak terhadap penerimaan aplikasi SIPKD (Sistem Pengelolaan Keuangan Daerah) dan penelitian Lie, I 
dkk yang menyatakan Faktor Sosial berpengaruh terhadap minat wajib pajak dalam menggunakan e-filing. (Lie, 2013).

2) Ekspektasi Kinerja berpengaruh positif terhadap Tax Billing System. Hal tersebut mengindikasikan bahwa Tax Billing System yang baru dilakukan oleh KPP Pratama Kebayoran Lama sejak 1 Januari 2016 sangat diharapkan oleh Wajib Pajak untuk dapat menambah kinerja aparat Pajak yang berarti juga menambah kinerja pelayanan terhadap Wajib Pajak. Ini mendukung hasil penelitian. Hasil penelitian mendukung hasil penelitian Iriani, Syono dan Ambarawati (2014) juga penelitian (Sari et al., 2016) yang menyimpulkan bahwa penerimaan aplikasi SIPKD dipengaruhi oleh faktor ekspektasi kinerja, ekspektasi usaha, pengaruh sosial dan kondisi yang memfasilitasi.

\section{Implikasi Penelitian}

1) Faktor sosial adalah pengaruh dari lingkungan yang meyakinkan seseorang untuk menggunakan suatu sistem. Faktor sosial ditunjukkan dari besarnya dukungan rekan kerja, atasan, dan organisasi. Hasil penelitian menyatakan Faktor Sosial berpengaruh signifikan terhadap Penggunaan Billing System Pajak. Hal ini mengandung implikasi agar kedepannya pihak fiskus lebih memperhatikan dan berusaha mewujudkan suatu kebiasaan yang mendukung penggunaan Billing System Pajak. Hal ini dapat dilakukan dengan mengadakan sosialisasi ke Wajib Pajak dengan lebih sering, membuat iklan sosialisasi, menyebarkan brosur dan lain sebagainya.

2) Ekpektasi Kinerja merupakan tingkatan kepercayaan pengguna apakah jika pengguna menggunakan sistem tersebut akan dapat meningkatkan kinerjanya. Ekspektasi Kinerja berpengaruh signifikan terhadap Billing System Pajak. Hal ini mengandung implikasi agar pihak fiskus lebih memperhatikan kinerja mereka yang terkait dengan pelayanan terhadap Wajib Pajak. Tidak hanya pelayanan melalui sistemnya yang diharapkan dapat diakses dengan cepat, aman dan mudah, tetapi juga pelayanan aparat pajak mulai dari garda terdepannya yakni keramahan dan kinerja dari Account Representatifnya. Diharapkan dengan kinerja yang semakin membaik dari pihak Fiskus maka Billing System juga semakin diminati oleh Wajib Pajak.

3) Faktor Sosial dan Ekspektasi Kinerja secara simultan berpengaruh signifikan terhadap Billing System Pajak, dilihat dari uji F 10,371 lebih besar dari $F$ tabel dengan degree of freedom 2 dan tingkat kesalahan 0,05 atau 5\% sebesar 3,090 dan juga signifikansi lebih kecil dari taraf signifikansi 0,05 yang berarti Faktor Sosial dan Ekspektasi Kinerja berpengaruh signifikan terhadap Billing System. Dengan melihat kegunaan, motivasi dan keuntungan yang dihasilkan dari penggunaan Billing System maka ekpektasi akan kinerja juga meningkat hal ini didukung dengan Faktor Sosial yakni pengaruh dari lingkungan sekitar, teman, rekan sejawat dan pimpinan.

\section{Keterbatasan Penelitian}

1) Keterbatasan waktu, sumber daya sehingga peneliti hanya menggunakan dua variabel independen dan 100 sample responden Wajib Pajak Orang Pribadi, sehingga hasil yang diperoleh hanya berlaku untuk Wajib Pajak Orang Pribadi, tidak termasuk Wajib Pajak Badan. Demikian juga keterbatasan hanya dengan penggunaan dua variabel saja, yang sebenarnya masih banyak untuk diteliti.

2) Dalam penelitian ini penentuan sampelnya menggunakan teknik Insidental Sampling (Convenience Sampling) yaitu penentuan sampel secara kebetulan, sehingga tidak menetapkan ciri-ciri khusus sesuai tujuan penelitian.

3) Penelitian ini hanya dilakukan dalam satu periode saja (cross sectional) sehingga hanya bisa mengungkapkan permasalahan pada saat itu juga.

Untuk penelitian selanjutnya disarankan untuk menambah data sampel dengan 
memperluas kriteria responden dan menambahkan variabel lainnya selain Ekspektasi Kinerja dan Faktor Sosial, misalkan variabel Pemahaman Pajak, Persepsi Wajib Pajak, Kualitas Sistem dan

\section{DAFTAR PUSTAKA}

Ajzen, I., \& Fishbein, M. (1980). Understanding attitudes and predicting social behaviour. PrenticeHall.

Atmojo, D. P. T. (2016). Analisis FaktorFaktor yang Mempengaruhi Minat Pemanfaatan Sistem Informasi dan Penggunaan Sistem Informasi (Studi Empiris pada Pemerintahan Daerah Kabupaten Banyuwangi). Artikel Ilmiah Mahasiswa. Universitas Jember.

Aydin, C. E., \& Rice, R. E. (1991). Social worlds, individual differences, and implementation: Predicting attitudes toward a medical information system. Information \& Management, 20(2), 119-136.

Azis, I. (2018). Pengaruh Penggunaan Sistem Teknolog Informasi dan Persepsi Mitra Kerja (Satker) terhadap Modul Penerimaan Negara Generasi Ke II (MPN G2) pada KPPN Makassar II. AKMEN Jurnal Ilmiah, 15(3).

Bisaria, S., \& Agarwal, P. (2017). Impact of Proposed GST on Electronic Billing: With Special Reference to Small Business Houses. Anwesh, 2(1), 14.

Damianus Andreas. (2017). Delapan Strategi Menkeu Tingkatkan Penerimaan Pajak. https://tirto.id/csXZ, diakses 22 Desember 2018.

Dashti, R., Yousefi, S., \& Moghaddam, M. P. (2013). Comprehensive efficiency evaluation model for electrical distribution system considering social and urban factors. Energy, 60, 53-61.

Dewi, Y. S. (2010). OLS, LASSO dan lainnya juga sangat disarankan agar menguji teori selain dari yang sudah digunakan dalam penelitian ini.

PLS Pada data Mengandung Multikolinearitas. Jurnal Ilmu Dasar, 11(1), 83-91.

Fishbein, M. (1979). A theory of reasoned action: some applications and implications. Nebraska Symposium on Motivation, 27, 65-116.

Gebauer, J., Shaw, M. J., \& Gribbins, M. L. (2010). Task-technology fit for mobile information systems. Journal of Information Technology, 25(3), 259-272.

Goodhue, D. L., \& Thompson, R. L. (1995). Task-technology fit and individual performance. MIS quarterly213-236.

Husnurrosyidah, H. (2017). Pengaruh EFiling, e-Billing dan e-Faktur Terhadap Kepatuhan Pajak pada BMT Se-Kabupaten Kudus. Jurnal Analisa Akuntansi dan Perpajakan 1(1).

Im, G. (2014). Effects of cognitive and social factors on system utilization and performance outcomes. Information \& management, 51(1), 129-137.

Iriani, S., Suyanto, M., \& Amborowati, A. (2014). Pengujian Sistem Informasi Pengelolaan Keuangan Daerah Berbasis Web Kabupaten Pacitan Dengan Menggunakan Unified Theory Of Acceptance And Use Of Technology (UTAUT). IJNSIndonesian Journal on Networking Security 3(2).

Janti, S. (2014). Analisis validitas dan reliabilitas dengan skala likert terhadap pengembangan si/ti dalam penentuan pengambilan keputusan penerapan strategic planning pada industri garmen. Paper presented at the Prosiding Seminar Nasional Aplikasi Sains \& Teknologi (SNAST). 
Jawas, F., Diatmika, I. P. G., AK, S., \& Yasa, I. N. P. (2018). Efektivitas Penerapan Sistem Elektronik dan Pelayanan Perpajakan terhadap Penerimaan Pajak (Studi Kasus pada Kantor Pelayanan Pajak Pratama Singaraja, Bali). JIMAT Undiksha

Jayakody, A., Bulathsinghala, A., Lihinigama, L., Anurad, K., \& Karunarathna, D. (2019). Performance Expectations for IT Graduates in Software Development. Global Journal of Computer Science Technology, 19(1).

Lie, I., \& Sadjiarto, R. A. (2013). FaktorFaktor Yang Mempengaruhi Minat Perilaku Wajib Pajak Untuk Menggunakan e-Filing. Tax and Accounting Review 3(2), 147.

Masoud, N. (2017). An empirical study of audit expectation-performance gap: The case of Libya. Research in International Business Finance, 41, 1-15.

Montano, D. E., Kasprzyk, D., \& practice. (2015). Theory of reasoned action, theory of planned behavior, and the integrated behavioral model. Health behavior: Theory, research, 70(4), 231.

Murry, M. S., Sinarwati, N. K., Yuniarta, G. A., \& AK, S. J. J. U. (2017). Persepsi Fiskus Dan Wajib Pajak Orang Pribadi (Wpop) Terhadap Penerapan E-Billing Pada Kantor Pelayanan Pajak (Kpp) Pratama Singaraja. 7(1).

Nugroho, R. A., Susilowati, A. D., Ambarwati, O. C., \& Pratiwi, A. (2018). Factors Affecting Users' Acceptance of E-Billing System in Surakarta Tax Office. ComTech: Computer, Mathematics Engineering Applications 9(1), 37-42.

Rey-Moreno, C., Ufitamahoro, M. J., Venter, I., \& Tucker, W. D. (2014).
Co-designing a Billing System for Voice Services in RuralSouth Africa: Lessons Learned. Paper presented at the Proceedings of the Fifth ACM Symposium on Computing for Development.

Rusli, Y. M. (2019). Pengaruh Efektivitas Penerapan E-Filing dan Modernisasi Sistem Perpajakan Indonesia terhadap Efektivitas Pemrosesan Data Perpajakan. Jurnal Akuntansi Bisnis, 12(1).

Rosnidah, I., Johari, R. J., Sulistyowati, W. A., Siddiq, D. M., \& Setiawan, A. (2018). Students' Intention in Pursuing Accounting Study: Theory of Planned Behaviour Perspective. Advanced Science Letters, 24(12), 9475-9478.

Sari, D. C. (2016). Determinan Penggunaan Sistem Informasi Pengelolaan Keuangan Daerah dan Pengaruhnya terhadap Ketepatan Waktu Pelaporan Keuangan SKPD. Jurnal Riset dan Aplikasi: Akuntansi dan Manajemen, 2(1), 17-30

Sulistyowati, W. A., Alrajawy, I., Yulianto, A., Isaac, O., \& Ameen, A. (2020). Factors Contributing to EGovernment Adoption in IndonesiaAn Extended of Technology Acceptance Model with Trust: A Conceptual Framework. In Intelligent Computing and Innovation on Data Science (pp. 651-658). Springer, Singapore.

Vetter, J. S., \& Worley, P. H. (2002). Asserting performance expectations. Paper presented at the SC'02: Proceedings of the 2002 ACM/IEEE Conference on Supercomputing.

West, D. M. (2004). E-government and the transformation of service delivery and citizen attitudes. Public administration review 64(1), 15-2 